\title{
Clerodane Diterpenoids from an Edible Plant Justicia insularis: Discovery, Cytotoxicity, and Apoptosis Induction in Human Ovarian Cancer Cells
}

\author{
Idowu E. Fadayomi ${ }^{1}$, Okiemute R. Johnson-Ajinwo ${ }^{1}$, Elisabete Pires ${ }^{2}$, James McCullagh ${ }^{2}$, Tim D. W. Claridge ${ }^{2}$, \\ Nicholas R. Forsyth ${ }^{1}(\mathbb{D})$ and Wen-Wu Li ${ }^{1, *} \mathbb{D}$ \\ 1 School of Pharmacy and Bioengineering, Keele University, Stoke-on-Trent ST4 7QB, UK; \\ i.e.fadayomi@keele.ac.uk (I.E.F.); okiemute_2002@yahoo.co.uk (O.R.J.-A.); n.r.forsyth@keele.ac.uk (N.R.F.) \\ 2 Department of Chemistry, University of Oxford, Mansfield Road, Oxford OX1 3TA, UK; \\ elisabete.pires@chem.ox.ac.uk (E.P.); james.mccullagh@chem.ox.ac.uk (J.M.); \\ tim.claridge@chem.ox.ac.uk (T.D.W.C.) \\ * Correspondence: w.li@keele.ac.uk; Tel.: +44-(0)1782-674382; Fax: +44-(0)1782-747319
}

Citation: Fadayomi, I.E.; Johnson-Ajinwo, O.R.; Pires, E.; McCullagh, J.; Claridge, T.D.W.; Forsyth, N.R.; Li, W.-W. Clerodane Diterpenoids from an Edible Plant Justicia insularis: Discovery, Cytotoxicity, and Apoptosis Induction in Human Ovarian Cancer Cells. Molecules 2021, 26, 5933. https://doi.org/10.3390/molecules 26195933

Academic Editor: Gian Cesare Tron

Received: 2 September 2021

Accepted: 26 September 2021

Published: 30 September 2021

Publisher's Note: MDPI stays neutral with regard to jurisdictional claims in published maps and institutional affiliations.

Copyright: (C) 2021 by the authors Licensee MDPI, Basel, Switzerland. This article is an open access article distributed under the terms and conditions of the Creative Commons Attribution (CC BY) license (https:/ / creativecommons.org/licenses/by/ $4.0 /)$.

\begin{abstract}
Objectives: The toxicity of chemotherapeutic anticancer drugs is a serious issue in clinics Drug discovery from edible and medicinal plants represents a promising approach towards finding safer anticancer therapeutics. Justicia insularis T. Anderson (Acanthaceae) is an edible and medicinal plant in Nigeria. This study aims to discover cytotoxic compounds from this rarely explored $J$. insularis and investigate their underlying mechanism of action. Methods: The cytotoxicity of the plant extract was evaluated in human ovarian cancer cell lines and normal human ovarian surface epithelia (HOE) cells using a sulforhodamine B assay. Bioassay-guided isolation was carried out using column chromatography including HPLC, and the isolated natural products were characterized using GC-MS, LC-HRMS, and 1D/2D NMR techniques. Induction of apoptosis was evaluated using Caspase 3/7, 8, and 9, and Annexin V and PI based flow cytometry assays. SwissADME and SwissTargetPrediction web tools were used to predict the molecular properties and possible protein targets of identified active compounds. Key finding: The two cytotoxic compounds were identified as clerodane diterpenoids: $16(\alpha / \beta)$-hydroxy-cleroda-3,13(14)Z-dien-15,16-olide (1) and 16oxo-cleroda-3,13(14)E-dien-15-oic acid (2) from the Acanthaceous plant for the first time. Compound 1 was a very abundant compound ( $0.7 \%$ per dry weight of plant material) and was shown to be more potent than compound 2 with $\mathrm{IC}_{50}$ values in the micromolar range against OVCAR- 4 and OVCAR- 8 cancer cells. Compounds $\mathbf{1}$ and $\mathbf{2}$ were less cytotoxic to HOE cell line. Both compounds induced apoptosis by increasing caspase $3 / 7$ activities in a concentration dependent manner. Compound $\mathbf{1}$ further increased caspase 8 and 9 activities and apoptosis cell populations. Compounds $\mathbf{1}$ and 2 are both drug like, and compound $\mathbf{1}$ may target various proteins including a kinase. Conclusions: Clerodane diterpenoids ( $\mathbf{1}$ and $\mathbf{2}$ ) in J. insularis were identified as cytotoxic to ovarian cancer cells via the induction of apoptosis, providing an abundant and valuable source of hit compounds for the treatment of ovarian cancer.
\end{abstract}

Keywords: ovarian cancer; Justicia insularis; diterpenoids; cytotoxicity; induction of apoptosis; target prediction

\section{Introduction}

Ovarian cancer is the most severe of the gynaecological malignancy worldwide, associated with the highest level of lethality due to lack of efficient screening method and early symptoms. Each year, ovarian cancer is diagnosed in about quarter of a million women worldwide, and it stands as the eighth commonest and seventh leading cause of cancer mortality among women, with 140,000 estimated casualties on a yearly basis [1]. At present, the available treatments for ovarian cancer include surgery, radiotherapy, chemotherapy, 
and immunotherapy. The most common chemotherapy drugs used for ovarian cancer treatment are carboplatin and paclitaxel. Others include cisplatin, gemicitabine, etoposide, topotecan, liposomal doxorubicin, and cyclophosphamide [2,3]. Targeted PARP inhibitors, such as Olaparib (Lynparza) and Niraparib (Zejula), and antibody based drugs, such as bevacizumab (Avastin) and rucaparib (Rubraca), are used with or after other chemotherapy for advanced ovarian cancer treatment [3]. These novel therapies have significantly improved the management of ovarian cancer. However, they have shortcomings, including severe side effects, development of resistance, and high cost. Therefore, the search for new and affordable drugs that could also reduce the adverse effects and overcome the resistant nature of cancer is highly essential.

Natural products from plants or their derivatives represent an important source of anticancer drugs, such as vinblastine, vincristine, topotecan and irinotecan, etoposide, and paclitaxel [2,4]. In particular, phytochemicals from edible and medicinal plants (e.g., isothiocyanates from cruciferous vegetables, sulforaphane from broccoli [5], curcumin from tumeric, genistein from soybean, resveratrol from grapes, and apigenin from various vegetables [6], etc.) are promising sources of anticancer compounds effective in the chemoprevention and treatment of cancer with lower costs and higher safety profiles with a plethora of mechanisms of action [7,8]. Plants in Nigeria have not been extensively explored to discover anti-cancer agents. Previously, we isolated and identified a number of promising cytotoxic alkaloids from several Nigerian medicinal plants [9-16].

Justicia insularis T. Anderson (Acanthaceae family) is an annual to perennial edible plant with medical use as digestive, weaning agent, laxative [17-19], and nutritional value [20] in Nigeria and across Africa. The Justicia is the largest genus with around 600 species, few of which have been studied in recent decades, although arylnaphthalide lignans and triterpenoid glycosides are indicated as the major types of chemical constituents [21]. Aqueous extracts of $J$. insularis leaves were shown to produce estradiol in vitro [17], promote ovarian folliculogenesis and fertility in female rats [19], possess anti-oxidant activity [20], and to benefit the treatment of anaemia [22]. However, the cytotoxic activity and chemical constituents of J. insularis have not been characterized. Here, we report the extraction, bioassay-guided purification/isolation, structural identification, cytotoxicity, apoptosis induction evaluation and target prediction in human ovarian cancer cells of the cytotoxic compounds from J. insularis.

\section{Materials and Methods}

\subsection{Reagents}

All the chemicals used were of analytical grade. $n$-Butanol, dichloromethane (DCM), ethyl acetate (EA), $n$-hexane, methanol $(\mathrm{MeOH})$, and trichloroacetic acid (TCA) were products of Fischer Scientific, Loughborough, UK. Cell culture media, Roswell Park Memorial Institute (RPMI) 1640, 10\% fetal bovine serum (FBS), L-glutamine, PENSTREP (50 $\mu \mathrm{g} / \mathrm{mL}$ penicillin/streptomycin), and phosphate buffered saline (PBS) were obtained from Lonza (Basel, Switzerland). Trizma base, trypsin-EDTA solution, glacial acetic acid, dimethyl sulfoxide (DMSO), sulforhodamine B (SRB) sodium salt, trypan blue, and carboplatin were purchased from Sigma Aldrich (St. Louis, MO, USA) and Caspase-Glo 3/7, 8, and 9 assay kits from Promega, Southampton, UK.

\subsection{Plant Samples}

Justicia insularis T. Anderson (Acanthaceae) leaves were sourced from Isiokolo in Kokori Town; Region/Local government area: Ethiope East; State: Delta, Nigeria (Latitude: $5^{\circ} 37^{\prime} 52^{\prime \prime} \mathrm{N}$; Longitude: $6^{\circ} 02^{\prime} 06^{\prime \prime} \mathrm{E}$ ), authenticated by Mr. Alfred Ozioko and deposited at the International Centre for Ethnomedicine and Drug Development (specimen voucher number: INTERCEDD/1590). The plants were pulverized after drying under shade for $7-10$ days at $25^{\circ} \mathrm{C}$. 


\subsection{Extraction Procedure for Justicia insularis}

The pulverized J. insularis leaves $(1.0 \mathrm{~kg})$ were macerated in $1000 \mathrm{~mL}$ of DCM and $1000 \mathrm{~mL}$ of $\mathrm{MeOH}$ for $72 \mathrm{~h}$. The mixture was filtered to obtain the DCM/MeOH extract. The residue was further macerated with $1000 \mathrm{~mL}$ of methanol for $72 \mathrm{~h}$. The solution of the extract was collected by filtration and repeated two more times within a $24 \mathrm{~h}$ maceration period. The residue was there after soaked in $1000 \mathrm{~mL}$ of deionized water and filtered after $72 \mathrm{~h}$ of maceration. This was also repeated two more times within $24 \mathrm{~h}$ each to increase the yield. The $\mathrm{DCM} / \mathrm{MeOH}$ extract was combined with methanol extract to yield the organic extract, which was dried using a rotary evaporator at $<40{ }^{\circ} \mathrm{C}$. The little remaining solvent was further removed using a desiccator. The aqueous extract was frozen at $-80^{\circ} \mathrm{C}$ for $24 \mathrm{~h}$ before being lyophilized to dryness.

\subsection{Solvent Partition of Plant Extracts}

The organic extract of $J$. insularis $(20 \mathrm{~g})$ was further partitioned with three solvents (n-hexane, ethyl acetate, and $n$-butanol) as done previously [9,15].

\subsection{Bioassay-Guided Purification of Bioactive Fraction of Justicia insularis}

The column was firstly prepared by suspending $50-80 \mathrm{~g}$ of silica gel in hexane. The suspended silica gel was poured into the column and allowed to settle with little solvent above the gel. The bioactive hexane or ethyl acetate fraction J. insularis was dissolved in hexane and gently transferred to the surface of the gel in the column using Pasteur pipette. The fractions were eluted with $200 \mathrm{~mL}$ of $n$-hexane/ethyl acetate in the following ratios (4:1, 3:1, 2:1, 1:1, 1:2, 1:3, and 1:4) consecutively based on the optimum thin layer chromatography profile obtained from a mobile phase of hexane and ethyl acetate combination. The column was finally washed using $100 \%$ methanol to obtain the more polar fractions. Ten sub-fractions were obtained using rotary evaporator and desiccator and their ovarian cancer cell growth inhibitory activities were evaluated using a cell growth assay on the OVCAR-4 cell line (Section 2.12). Each of the sub-fractions from the ethyl acetate fraction showed significant anti-cancer activity. However, EA4 was the most active sub-fraction of the ethyl acetate fraction while the least activities were observed in EA9 and EA10 which were eluted with ethyl acetate/methanol and methanol respectively. EA4 was further purified using column chromatography to yield sub-fractions of EA4. The growth inhibitory activity of the sub-fractions of EA4 from column chromatography was evaluated. Sub-fractions EA4-4 and EA4-6 were further purified using semi-preparative high performance liquid chromatography.

\subsection{Isolation of Compound $\mathbf{1}$ and $\mathbf{2}$ Using High Performance Liquid Chromatography (HPLC)}

The various sub-fractions were further assayed for anti-cancer activities and the most significant active sub-fractions were purified further using semi-preparative HPLC. Briefly, semi-preparative HPLC was done using Agilent 1220 LC, USA. The mobile phase used two solvent systems. Solvent A consisted of $100 \%$ water and solvent B was $100 \%$ methanol. The mobile phase calibration rose from $50 \%$ by $50 \%$ (A:B) over a period of $25 \mathrm{~min}$ to $100 \%$ B and kept at $100 \%$ for $10 \mathrm{~min}$ at a flow rate of $4 \mathrm{~mL} / \mathrm{min}$ at $215 \mathrm{~nm}$ on semi-preparative HPLC column (Phenomenex, Cambridgeshire, UK; $5 \mu \mathrm{m}$ particle size: $9.4 \times 250 \mathrm{~mm}$ ). A major fraction and minor fraction eluted at retention times of 22 and $24 \mathrm{~min}$ were collected and dried using a rotary evaporator to yield compound $\mathbf{1}(80 \mathrm{mg}, 97 \%$ purity) and compound 2 ( $2 \mathrm{mg}, 85 \%$ purity), respectively.

\subsection{Quantification of Compound $\mathbf{1}$ in the Extracts and Plant Materials}

The purity of both compounds and the composition of compound $\mathbf{1}$ in the total plant organic extracts were determined by using analytical HPLC. Stock solutions of the highly pure compound 1 with a series of concentrations $(0.125,0.25,0.5,1.0$ and $1.5 \mathrm{mg} / \mathrm{mL})$, and organic extracts solutions at $1.0 \mathrm{mg} / \mathrm{mL}$ were prepared. Hence, $10 \mu \mathrm{L}$ of each stock solution and samples were injected into the analytical HPLC system in duplicates. The 
mobile phase rose from $20 \% \mathrm{~B}(\mathrm{~A}+\mathrm{B})$ to $100 \% \mathrm{~B}$ over a period of $25 \mathrm{~min}$ and kept at $100 \%$ for $6 \mathrm{~min}$ at $215 \mathrm{~nm}$ on an analytical HPLC column (Phenomenex, UK; $5 \mu \mathrm{m}$ particle size, $4.6 \times 250 \mathrm{~mm}$ ) at a flow rate of $1 \mathrm{~mL} / \mathrm{min}$. For the quantification of compound 1 in organic extracts, a linear calibration curve was made by plotting the area under the peak against the different contractions. The percentage of compound $\mathbf{1}$ in the organic extracts was calculated based on the calibration curve.

\subsection{Gas Chromatography Mass Spectrometry Analysis}

Briefly, 1.0-2.0 mg of the bioactive fractions and isolated compounds of $J$. insularis were dissolved in $200 \mu \mathrm{L}$ of ethyl acetate and sonicated at $<40{ }^{\circ} \mathrm{C}$ for $5 \mathrm{~min}$. $1-2 \mu \mathrm{L}$ of the solution was subsequently injected into gas chromatography mass spectrometry (GC-MS) system consisting of an Agilent 7890 coupled to Agilent MS model 5975C MSD (Agilent Technologies, Cold Spring, NY, USA). The gas chromatography started at $60^{\circ} \mathrm{C}$ for 2 min and increased to $300{ }^{\circ} \mathrm{C}$ at the rate of $10{ }^{\circ} \mathrm{C} / \mathrm{min}$, which was held at $300{ }^{\circ} \mathrm{C}$ for $4 \mathrm{~min}$ at a constant helium pressure (10 psi). The mass spectra data were acquired in the scan mode in $m / z$ range $40-1000$.

\subsection{Liquid Chromatography Mass Spectrometry (LC-MS) Analysis}

The purified compounds were analysed by LC-MS to determine their high resolution molecular mass using a Ultimate U3000 ultra-performance liquid chromatography system with a HESI II electrospray ion source on a Q-Exactive Orbitrap mass spectrometer system (Thermo Scientific, Waltham, MA, USA) as described [12].

\subsection{NMR Spectroscopy}

$1 \mathrm{D}$ and 2D NMR spectra of compounds $\mathbf{1}$ and $\mathbf{2}$ were obtained with a Bruker AVII500 NMR spectrometer (Billerica, MA, USA). 1D NMR spectra of the hexane fraction of J. insularis were obtained with a Bruker Ascend 400 NMR spectrometer. ACD/Labs 10 Freeware (Advanced Chemistry Development Inc., Toronto, ON, Canada) or Bruker TopSpin 4.1.3 software was used to analyse the NMR Spectra.

\subsection{Cell Culture}

The human ovarian cancer cell lines and normal human ovarian surface epithelial (HOE) cells were used in this study. Ovarian cancer cell lines (OVCAR-4 and OVCAR-8) were products of American tissue culture collection (ATCC). The HOE cells were purchased from Applied Biological Materials (ABM) Inc. (Vancouver, BC, Canada). The Rosewell Park Memorial Institute (RPMI 1640, Lonza) medium was used in the culturing of OVCAR-4, OVCAR-8, and HOE cells. The medium was supplemented with $2 \mathrm{mM}$ glutamine, $10 \%$ foetal bovine serum (FBS), and $50 \mu \mathrm{g} / \mathrm{mL}$ penicillin streptomycin. These cells were incubated in a standard humidified incubator) at $37^{\circ} \mathrm{C}, 5 \%$ carbon dioxide $\left(\mathrm{CO}_{2}\right)$ conditions.

\subsection{Sulforhodamine B Cell Growth Inhibitory Assay}

Sulforhodamine B (SRB) assay was used to determine the inhibition of cell proliferation by the studied compounds and plant extracts $[9,10,15]$. Plant extracts / fractions (100 $\mathrm{mg} / \mathrm{mL})$ and pure compounds $(20 \mathrm{mM})$ were prepared in DMSO. The $0.2 \%$ DMSO in growth media was added to the cells as vehicle-treated cells (negative control) while carboplatin was used as positive control. In the SRB assay, OVCAR-4, OVCAR-8, and HOE cells were seeded in $80 \mu \mathrm{L}$ growth medium per each well in 96 well plates. OVCAR-4 and HOE were seeded at a density of 5000 cells per well while OVCAR- 8 was seeded at a density of 2000 cells per well. The seeded plates were incubated for $24 \mathrm{~h}$, after which $20 \mu \mathrm{L}$ of plant extracts and natural compounds $1000 \mu \mathrm{g} / \mathrm{mL}$ and $200 \mu \mathrm{M}$ (and their serial two-fold dilutions), respectively, were added at the indicated concentrations. The cell cultures were incubated at $37^{\circ} \mathrm{C}$ under $5 \% \mathrm{CO}_{2}$ for $72 \mathrm{~h}$ in a humidified atmosphere. 
After $72 \mathrm{~h}$, the medium was decanted, and the cells fixed with $0.1 \mathrm{~mL}$ of $10 \%$ TCA on ice for $30 \mathrm{~min}$ before drying. The cells were stained with $0.4 \% \mathrm{SRB}$, washed with $1 \%$ acetic acid three times and dried. Then, $0.1 \mathrm{~mL}$ of Tris-base $(10 \mathrm{mM})$ was added to the plates to solubilise the protein-bound SRB dye. The absorbance at $570 \mathrm{~nm}$ was measured using a spectroscopic plate reader (Multi-mode microplate reader BioTEK Synergy 2, Winooski, VT, USA). The data were analysed by non-linear regression to fit a 4-parameter sigmoidal dose-response curve to determine $\mathrm{IC}_{50}$ values using GraphPad PRISM 6.0 software, Inc. (San Diego, CA, USA).

\subsection{Apoptosis Detection Using Caspase-Glo 3/7, 8 and 9 Activity Assay}

Caspase 3/7 activities was measured using assay kits caspase-Glo $3 / 7$ (Promega Corp., Madison, WI, USA) on a 96-well microplate. Briefly, the cells (OVCAR-4 and OVCAR-8) were seeded in 96 well plates at a cell density of 5000 cells/well in $80 \mu \mathrm{L}$ growth media and exposed to 10, 20 and/or $30 \mu \mathrm{M}$ of the natural compounds after $24 \mathrm{~h}$ incubation. After $48 \mathrm{~h}$ exposure to compound treatments, $25 \mu \mathrm{L}$ of Caspase 3/7 Glo-reagent was added, and the cells were incubated in the dark at room temperature for $30 \mathrm{~min}$ on a gentle rocker. The luminescence was measured at $570 \mathrm{~nm}$ by a BioTEK Synergy microplate reader (USA). A similar procedure was followed for caspase 8 and caspase 9 activity.

\subsection{Evaluation of Early and Late Apoptosis Using Flow Cytometry}

The in vitro method of fluorescence-activated cell sorting (FACS) by Annexin V and propidium iodide (PI) staining was used to detect the change of cell population as reported [10,23]. OVCAR-8 cells were seeded in 12 well plates at a density of $2 \times 10^{5}$ cells per well in $1 \mathrm{~mL}$ of growth media and incubated for $24 \mathrm{~h}$ before treatment with the tested compound and positive control. After treatment for $48 \mathrm{~h}$, media were decanted into $15 \mathrm{~mL}$ tubes, and cell pellets were collected into the same tubes by trypsinisation, the cells were centrifuged at $150 \times g$ for $3 \mathrm{~min}$ and re-suspended into $1 \mathrm{~mL}$ growth media, which was transferred into sterile $2 \mathrm{~mL}$ Eppendorf tube, centrifuged at $300 \times g$ for $5 \mathrm{~min}$ at $4{ }^{\circ} \mathrm{C}$. The media were aspirated, and the pellet was washed in cold PBS. The cells were centrifuged under the same conditions and the supernatant aspirated. Cells were washed in $500 \mu \mathrm{L}$ annexin-V binding buffer and centrifuged at $300 \times g$ for $10 \mathrm{~min}$, annexin-V binding buffer was aspirated, and the cell pellet was treated with $10 \mu \mathrm{L}$ of annexin V-FITC in $100 \mu \mathrm{L}$ of binding buffer. The cells were thoroughly mixed and incubated in the dark at room temperature for $15 \mathrm{~min}$. After incubation, cells were washed in binding buffer and centrifuged at $300 \times g$ for $10 \mathrm{~min}$. The buffer was aspirated, and cells were suspended in $500 \mu \mathrm{L}$ binding buffer and subsequently $5 \mu \mathrm{L}$ of PI was added for flow cytometry analysis.

\subsection{Bioinformatic Analysis}

The molecular properties of compounds 1 and $\mathbf{2}$ were determined or predicted through the SwissADME website tool [24,25], and their molecular targets predicted through SwissTargetPrediction (Swiss Institute of Bioinformatics, University of Lausanne, Lausanne, Switzerland) web tool $[26,27]$.

\subsection{Statistical Analysis}

The $\mathrm{IC}_{50} \mathrm{~s}$ were obtained from at least three repeated experiments. The mean $\mathrm{IC}_{50}$ was calculated, and the standard error of mean (SEM) was determined. Furthermore, a one way analysis of variance (ANOVA) and student $t$ test were used to test if the difference in the mean of control and treatments and mean of treatment at different concentration were significant. A post hoc Dunnett test was used to determine which of the treatments was significant to the control while a Tukey test was used to determine which of the concentrations of a particular treatment were significant using GraphPad prism 6. 


\section{Results}

\subsection{Bioassay-Guided Isolation of Diterpenoids from J. insularis}

The bioassay-guided fractionation and isolation of two diterpenoids from extracts of J. insularis are illustrated (Figure S1 in the Supplementary Materials). Both organic ( $21.0 \mathrm{~g}$, $2.1 \%$ yield) and aqueous extracts of J. insularis were obtained. The organic extracts were partitioned with solvents and the weights and yields of the solid fraction recovered are $4.6 \mathrm{~g}(25 \%), 6.0 \mathrm{~g}(33.3 \%), 2.5 \mathrm{~g}(13.9 \%)$, and $3.0 \mathrm{~g}(16.7 \%)$ for $n$-hexane, ethyl acetate (EA), $n$-butanol, and aqueous fractions respectively.

The organic extract showed stronger cytotoxicity against OVCAR-4 and OVCAR-8 cell lines $\left(\mathrm{IC}_{50}<30 \mu \mathrm{g} / \mathrm{mL}\right.$ ) than the aqueous extract J. insularis using SRB cell growth assay. Furthermore, that n-hexane and ethyl acetate fractions derived from the organic extract are the most active fractions with $\mathrm{IC}_{50}$ less than $20 \mu \mathrm{g} / \mathrm{mL}$ (Figure S2, Table S1). Analytical HPLC analysis of both n-hexane and ethyl acetate fractions showed similar patterns of compounds. The more abundant ethyl acetate fraction of J. insularis was focused on and subjected to silica gel column chromatography. Ten sub-fractions were obtained, and their in vitro ovarian cancer growth inhibitory activities were evaluated (Table S2). The most active sub-fraction (EA4) was further purified using reversed-phase HPLC to yield compounds $\mathbf{1}$ and $\mathbf{2}$ with high purity (Figure S3).

\subsection{Chemical Identification of the Isolated Bioactive Compounds of J. insularis}

The molecular formula of $\mathbf{1}$ was determined as $\mathrm{C}_{20} \mathrm{H}_{30} \mathrm{O}_{3}$ based on the observed molar mass of compound 1 (found, 318.2123 Da) by LC-HR-MS (Figure S4). Compound 1 (Figure 1) was identified as 1:1 mixture of 16-hydroxy epimers ( $\alpha$ and $\beta$ ) of 16-hydroxycleroda-3,13(14)Z-dien-15,16-olide based on GC-MS (Figure S5), ${ }^{1} \mathrm{H},{ }^{13} \mathrm{C}-\mathrm{NMR}$ and HSQC analysis (Figure S6, Table S3) and a comparison with literature data [28-30]. ${ }^{13} \mathrm{C}-\mathrm{NMR}$ spectrum of the hexane fraction (Figure S6) showed the presence of epimers of compound 1 before silica gel chromatography and HPLC purification which may cause isomerization, so the epimers of compound $\mathbf{1}$ are the natural products in J. inuslaris. Compound $\mathbf{1}$ showed a single peak in analytical HPLC chromatogram indicating a purity of 97\% (Figure S3). Surprisingly, three major peaks appeared on the GC-MS chromatogram (Figure S5), the mass spectrum of a peak at retention time $18.45 \mathrm{~min}$ is consistent with the mass data of compound 1 [24]. The other observed compounds, $1 \mathrm{a}$ and $1 \mathrm{~b}$ (Figure S5), were determined to be the thermal degradation products of compound $\mathbf{1}$ due to the presence of a $\gamma$-hydroxy unsaturated 5-membered lactone moiety (Figure 1) under high temperature conditions $\left(60{ }^{\circ} \mathrm{C}-300{ }^{\circ} \mathrm{C}\right)$ for $30 \mathrm{~min}$ of GC-MS. To support this, the exposure of compound $\mathbf{1}$ at $200{ }^{\circ} \mathrm{C}$ for $0.5 \mathrm{~h}$ followed by HPLC analysis indicated the formation of new products (likely including $\mathbf{1 a}$ and $\mathbf{1 b}$ ), whose structures remain to be determined. Furthermore, the percentage of compound 1 in organic extracts was determined to be $34 \%$. Thus, the composition of compound $\mathbf{1}$ in the plant material is $0.7 \%$ (dry weight), a very abundant secondary metabolite in the leave of $J$. insularis.

Compound 2 (Figure 1) has the same molecular formula $\mathrm{C}_{20} \mathrm{H}_{30} \mathrm{O}_{3}$ as compound $\mathbf{1}$ by LC-HRMS data (Figure S7), which was further identified as 16-oxo-cleroda-3,13(14)E-dien15-oic acid based on ${ }^{1} \mathrm{H}-\mathrm{NMR},{ }^{13} \mathrm{C}-\mathrm{NMR}$ and HSQC analysis (Figure S8) and a comparison with literature data (Table S3) [28,29]. 


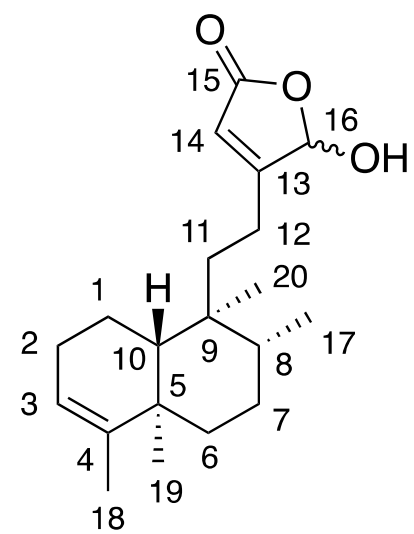

1

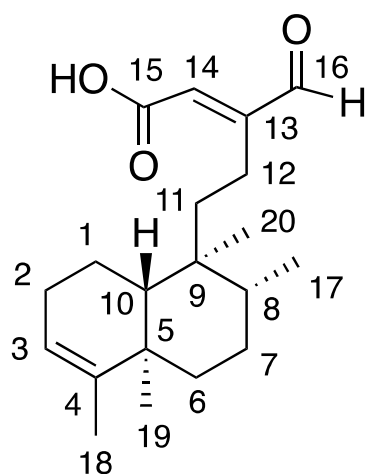

2

Figure 1. Chemical structure of compound 1, 16( $\alpha / \beta)$-hydroxy-cleroda-3,13 (14)Z-dien-15,16-olide, and compound 2, 16-oxo-cleroda-3,13(14)E-dien-15-oic acid.

\subsection{In Vitro Cytotoxicity of Compounds $\mathbf{1}$ and $\mathbf{2}$}

Compound $1\left(\mathrm{IC}_{50}=4-6 \mu \mathrm{M}\right)$ shows greater potency than compound $2\left(\mathrm{IC}_{50}=\right.$ 12-17 $\mu \mathrm{M}$ ) and a positive control carboplatin $\left(\mathrm{IC}_{50}=8-18 \mu \mathrm{M}\right)$ (Table 1$)$ against OVCAR-4 and OVCAR-8 cells (Figure 2). Both compounds 1 and $\mathbf{2}$ demonstrate less cytotoxic activity against HOE cells (Table 1).

Table 1. The growth inhibitory activities of isolated compounds (1 and 2) from J. insularis in OVCAR-4, OVCAR-8 cancer cell lines and HOE cells. The selectivity index (SI) (the ratio of $\mathrm{IC}_{50}$ against HOE cells to $\mathrm{IC}_{50}$ against OVCAR-8) are indicated.

\begin{tabular}{ccccc}
\hline Compounds & $\begin{array}{c}\text { OVCAR-4 } \\
(\boldsymbol{\mu M})\end{array}$ & $\begin{array}{c}\text { OVCAR-8 } \\
(\boldsymbol{\mu M})\end{array}$ & $\begin{array}{c}\text { HOE } \\
(\boldsymbol{\mu M})\end{array}$ & $\begin{array}{c}\text { SI against } \\
\text { OVCAR-8 }\end{array}$ \\
\hline $\mathbf{1}$ & $5.7 \pm 0.3(1.8 \mu \mathrm{g} / \mathrm{mL})$ & $4.4 \pm 0.2(1.4 \mu \mathrm{g} / \mathrm{mL})$ & $12.1 \pm 0.1(3.9 \mu \mathrm{g} / \mathrm{mL})$ & 3 \\
$\mathbf{2}$ & $16.6 \pm 2.8(5.3 \mu \mathrm{g} / \mathrm{mL})$ & $11.8 \pm 0.5(3.8 \mu \mathrm{g} / \mathrm{mL})$ & $22.8 \pm 0.7(7.3 \mu \mathrm{g} / \mathrm{mL})$ & 2 \\
Carboplatin & $17.6 \pm 4.6$ & $8.2 \pm 2.2$ & $13.0 \pm 3.7$ & 1.6 \\
\hline
\end{tabular}

(A)

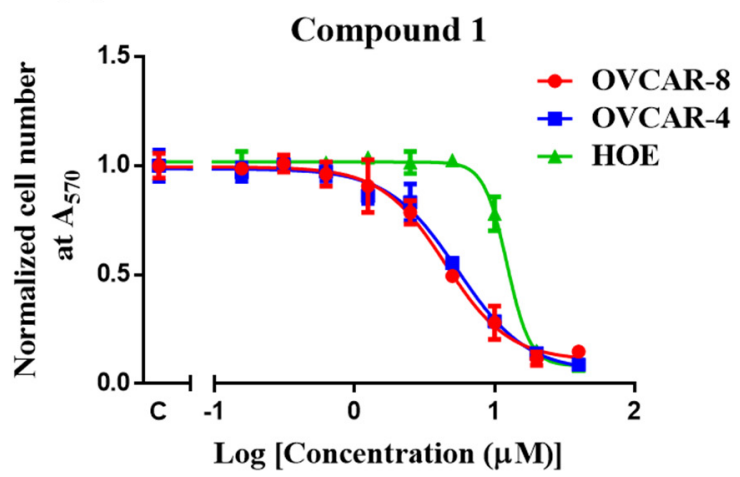

(B)

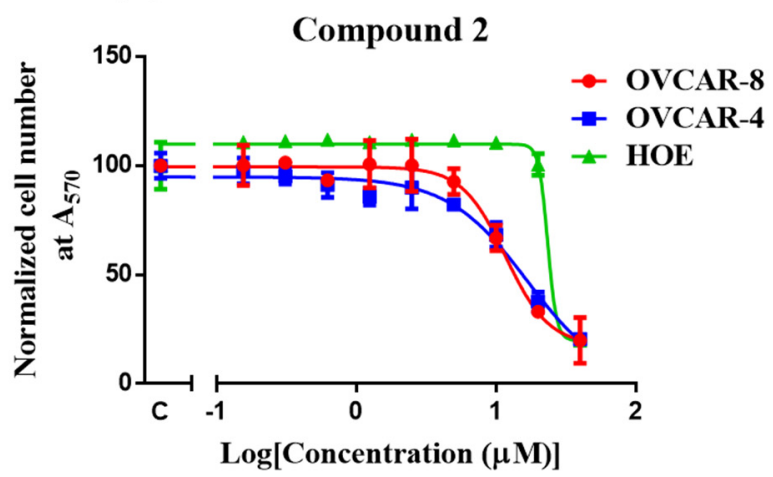

Figure 2. Mean concentration-response curve of compound $\mathbf{1}(\mathbf{A})$ and $\mathbf{2}(\mathbf{B})$ in OVCAR-4 and OVCAR-8 ovarian cancer cells and HOE. $\mathrm{IC}_{50}$ values determined are listed in Table 1.

\subsection{Apoptosis Study}

To investigate whether the significant decrease in cell viability by compound $\mathbf{1}$ and $\mathbf{2}$ was due to apoptosis, the level of caspase $3 / 7$, or caspase 8 and 9 activation by these compounds were measured. Compound 1 and 2 significantly increased caspase $3 / 7$ activities in OVCAR-4 and OVCAR-8 cells when compared with control using one-way analysis of variance (ANOVA) (Figure 3A,B). Compound 1 further increased caspase 8 and 9 activi- 
ties in OVCAR-8 (Figure 3C,D). These results suggest that the significant decrease in cell viability induced by these compounds was likely due to apoptosis.

(A)

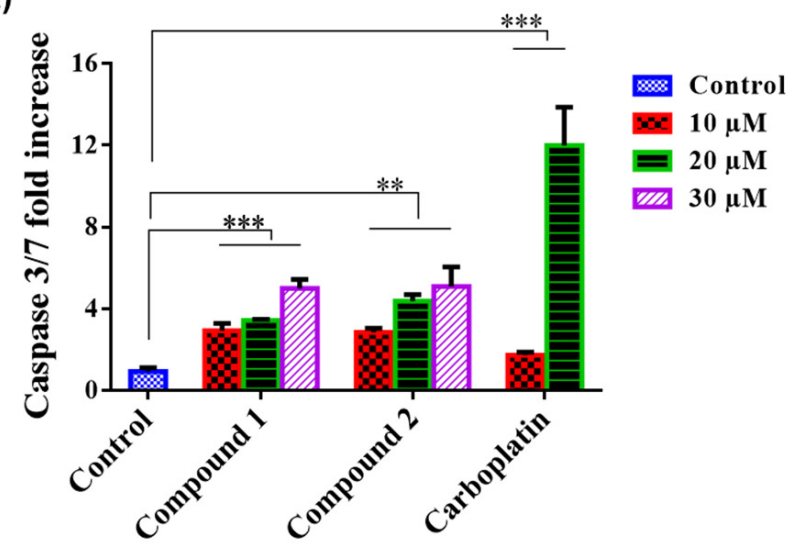

Treatment Administered on OVCAR-4 for $48 \mathrm{~h}$

(C)

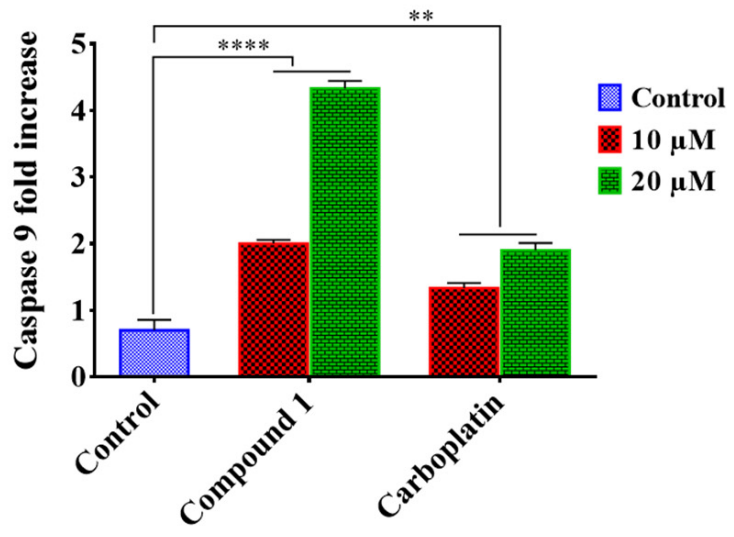

Treatment Administered on OVCAR-8 for $48 \mathrm{~h}$
(B)

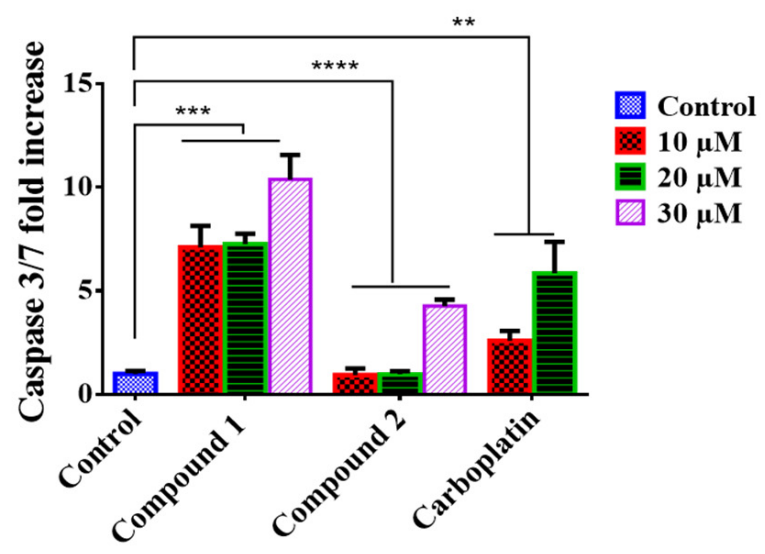

Treatment Administered on OVCAR-8 for $48 \mathrm{~h}$

(D)

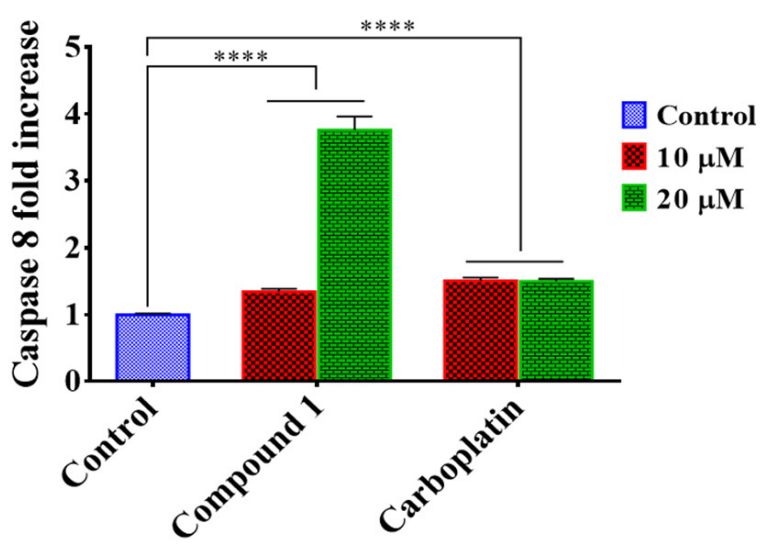

Treatment Administered on OVCAR-8 for 48 h

Figure 3. Caspase activities of compound 1 and $\mathbf{2}$ in ovarian cancer cells. Caspase $3 / 7$ activities of isolated compound 1 and 2 in OVCAR-4 (A) and OVCAR-8 (B) cells; and caspase 8 activity (C) and caspase 9 activity (D) of compound $\mathbf{1}$ in OVCAR-8 cells. Carboplatin was used as positive control. The fold increase in caspase activities induced by compound 1 and positive control were compared with the negative control using one-way ANOVA with Dunnett's multiple comparison test. Significant difference between treatment and control is denoted with asterisk $\left(^{*}\right)$ and student $t$ test was used to test for concentration dependent activity.

Furthermore, annexin-V and PI assay results also show concentration-dependent and significant increase of percentage of early and late apoptosis induced by compound $\mathbf{1}$ (at 5 , 10, and $20 \mu \mathrm{M}$ ) after $48 \mathrm{~h}$ treatment (Figure 4), similar to the positive control carboplatin same concentrations. 
(A)

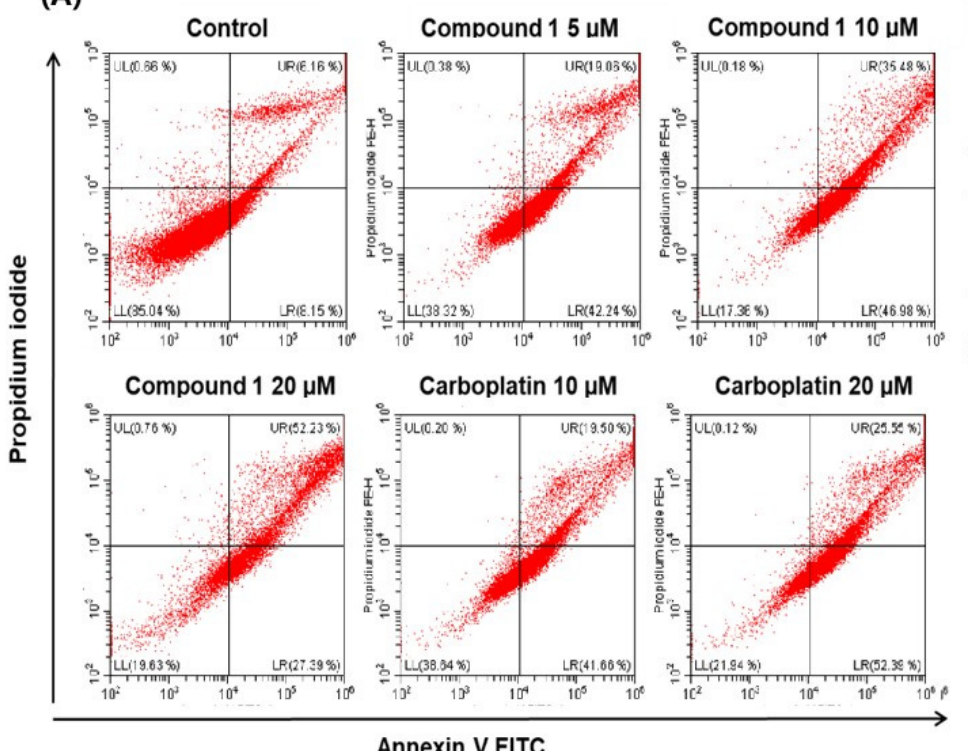

(B)

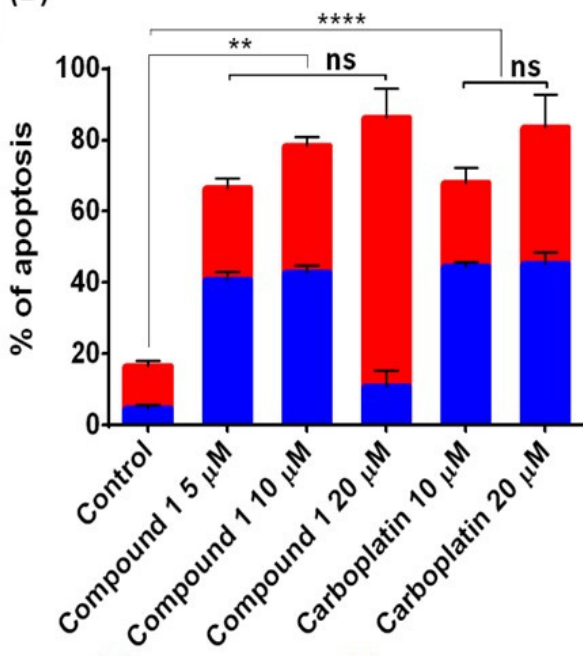

Late apoptosis Early apoptosis

Analysis of apoptosis in OVCAR-8 cell line

Figure 4. Evaluation of apoptotic activities of compound $\mathbf{1}(5,10$ and $20 \mu \mathrm{M})$ and carboplatin $(10$ and $20 \mu \mathrm{M})$ on OVCAR-8 cells using annexin V-FITC and propidium iodide (PI) staining analysed with flow cytometry. (A) Representative flow cytometry graphs of OVCAR-8 cell line. Lower left (LL), upper left (UL), lower right (LR) and upper right (UR) represent live cells, necrotic cells, cells in early apoptosis and cells in late apoptosis respectively. (B) Mean percentage of apoptotic cell populations. The data represent the mean $\pm \mathrm{SD}$ of three repeats. The significant different between control and treatment is denoted with asterisk $\left(^{*}\right)$, while no significant different is denoted with (ns).

\subsection{Bioinformatic Analysis}

Compounds 1 and $\mathbf{2}$ have the same molecular formula, with $\mathbf{1}$ having a more rigid structure than 2 . Both compounds are druglike, obeying the Lipinski rule (Table S4). The possible targets of compound $\mathbf{1}$ are predicted to be mainly kinase (e.g., Ribosomal protein S6 kinase alpha 5), primary active transporters (e.g., potassium-transporting ATPase alpha chain 2), and nuclear receptors (e.g., glucocorticoid receptor) (Table S5, Figure S9), while the possible targets of compound 2 are predicted to be nuclear receptors (e.g., estrogen receptor beta), oxidoreductases (e.g., steroid 5-alphareductase 2), and phosphatases (e.g., proteintyrosine phosphatase 1B) (Table S6, Figure S10), although with low probability $(<25 \%)$.

\section{Discussion}

The ethnopharmacological use and the anti-cancer activity of Justicia species [31-33] inspired us to investigate the cytotoxic activities of J. insularis from Nigeria against ovarian cancer cells. In this study, two clerodane diterpenoid compounds ( $\mathbf{1}$ and $\mathbf{2}$ ) were revealed to be the cytotoxic compounds in J. insularis for the first time. The very abundant compound 1 in the plant extracts showed higher potency with $\mathrm{IC}_{50}$ values $<6 \mu \mathrm{M}$ against the two ovarian cancer cell lines studied and greater SI compared to those of a standard chemotherapeutic drug carboplatin for ovarian cancer treatment. This makes compound $\mathbf{1}$ an interesting hit compound. The cytotoxic activity of compound $\mathbf{1}$ is likely associated with the more rigid $\alpha, \beta$-unsaturated $\gamma$-lactone moiety in the clerodane diterpenoid, whereas compound $\mathbf{2}$ with an open form and more rotational bonds (Table S4) demonstrates less cytotoxicity [34]. Compound 1 was found to be thermally unstable at a high temperature, and further isolation, identification, and testing the cytotoxicity of those degradation compounds (Figure S5) would be interesting. Compound 1 was found to be a mixture of epimers of $16 \alpha(\mathrm{S})$ and $16 \beta(\mathrm{R})$ forms (1:1) based on the analysis of NMR spectra of the isolated compound 1 and the hexane fraction before purification (Figure S6). The single epimer $16 \alpha$ (S) form of compound 1 was previously isolated from P. longifolia [28], P. barnesii [35], and P. simiarum [36] (the Annonaceae family). A mixture of 16S and 16R epimers (1:1) 
was also found in P. longifolia [24] and chemically synthesized [30]. Compound 2 was also present in P. longifolia [28,29]. Previously, phytochemical studies of Justicia species disclosed the presence of cytotoxic lignans, such as justicidin A $[37,38]$ and $6^{\prime}$-hydroxy justicidin A [32] from J. procumbens and triacontanoic ester of 5-hydroxy-justisolin from J. simplex [31]. Chemical analysis of leave extract of J. insularis indicated the presence of abundant iron [20] and hemoglobin, which might explain the observed benefit for anaemia [22]. Our study indicates the clerodane diterpenoids, such as compounds $\mathbf{1}$ (abundant) and $\mathbf{2}$, are present in the family of Acanthaceae, providing a new source of these interesting compounds as hit compounds for anticancer drug development.

Cancer cells are generally known for their characteristic features of escaping programmed cell death (apoptosis), which is a mechanism that maintains the cell population and defense against damaged cells [39]. To further investigate the route of anticancer activity for compound $\mathbf{1}$ and $\mathbf{2}$, their roles in the induction of apoptosis were evaluated. The caspase 3/7 activity of compounds 1 and 2 was evaluated, and the results showed that the cell death induced by compounds 1 and 2 was via the activation of caspase 3/7 which are apoptosis executioners. Furthermore, compound 1 activated both caspase 8 and 9, which indicates the involvement of both extrinsic and intrinsic pathway [39]. Compound 2 was not further investigated due to the lesser activity and limited quantity isolated. The pro-apoptotic activity of compound $\mathbf{1}$ was further verified using annexin V-FITC and PI staining, which analysed the apoptotic markers, i.e., phosphatidylserine residues, on the cell surfaces and DNA fragments in the nucleus, respectively [23]. The percentages of both early and late apoptotic cells caused by compound $\mathbf{1}$ are similar to those of carboplatin. Further bioinformatic analysis of the potential protein targets of compounds $\mathbf{1}$ and $\mathbf{2}$ supports the observed greater cytotoxicity and apoptotic activity of compound $\mathbf{1}$ than $\mathbf{2}$, because compound $\mathbf{1}$ may more likely target kinases which are essential for cancer cell initiation and proliferation [40]. The cytotoxicity and induction of apoptosis of compound $\mathbf{1}$ were previously observed in other cancers, such as leukaemia HL-60 [41], CML K562 [42,43], oral squamous cell carcinoma cancer [44], human renal carcinoma [45], renal cell carcinoma [46], T24 bladder cancer [47], and breast cancer [48] cells. Specifically, compound 1 induces the expression of PRC2 enzyme complex in CML K562 cells [42] and deregulates phosphoinositide-3 kinase (PI3K) and Aurora kinase B activities [43]. Compound $\mathbf{1}$ was also found to be involved with Akt, mTOR, and MEK-ERK pathways in renal carcinoma cells [45] or the inactivation of EGFR-related pathways in bladder cancer cells [47]. Our study is the first report showing their cytotoxicity in ovarian cancer cells via the induction of apoptosis via both intrinsic and extrinsic pathways, which is consistent with its cytotoxicity found in other cancers.

Besides the cytotoxic activity of these diterpenoids, $16 \alpha$-hydroxy-cleroda-3,13(14)Zdien-15,16-olide (1) was also demonstrated to be an orally active anti-leishmanial and non-cytotoxic agent [49], a HMG-CoA reductase inhibitor [50], and a dual inhibitor of COX/5-LOX with potential in the treatment of inflammatory conditions [51,52]. Compound 2 possesses anti-biofilm activity against methicillin resistant Staphylococcus aureus and Streptococcus mutans [53].

Diterpenoids are a large group of natural products with diverse structures and biological activities including anticancer activity [34,54]. One of the well-known and approved anticancer diterpenoid drug from plants is paclitaxel, which showed superior potency against ovarian cancer cells with $\mathrm{IC}_{50} \mathrm{~s}$ at nanomolar range through stabilizing the tubulin structure of cancer cells [55]. However, it also caused severe side effects among patients because of its poor selectivity to cancer cells. So far, more than hundreds of important diterpenoids, including triptolide, oridonin, and andrographolide, have been discovered and shown in vitro and/or in vivo cytotoxicity with moderate and strong potency [54]. Specifically, clerodane diterpenoids were isolated and showed cytotoxicity to various cancer cell lines [34]. For example, caseamembrins A-F from Casearia membranacea showed cytotoxicity to human prostate cancer $\mathrm{PC}-3$ cells with $\mathrm{IC}_{50}$ at the $\mu \mathrm{M}$ range with either intrinsic or extrinsic apoptotic pathways [56]. Ent-clerodane diterpenoids from Scutellaria barbata D. 
Don. (Labiatae) showed cytotoxicity against KB oral epidermoid carcinoma, HONE-1 nasopharyngeal, and HT29 colorectal carcinoma cells with $\mathrm{IC}_{50}$ values in the range of 3.1-7.2 $\mu \mathrm{M}$ [57]. Kurzipene B from the leaves of Casearia kurzii showed an $\mathrm{IC}_{50}$ value of $5.3 \mu \mathrm{M}$ against Hela cells, induced apoptosis, and arrested the cell cycle at the $\mathrm{G}_{0} / \mathrm{G}_{1}$ stage [58]. The activity of the two compounds found in J. insularis is comparable to clerodane diterpenoids from other plants.

Further work on the experimental identification of molecular targets, structure-activity relationships, efficacy, and safety of diterpenoids in J. insularis remain under investigation in in vitro and animal xenograft models, which may provide a safer, more sustainable, and affordable anticancer drug.

\section{Conclusions}

This study shows that the extract of the edible J. insularis leaves demonstrate significant cytotoxic activities against ovarian cancer cell lines, providing a new and abundant potential source of anticancer agents. Two diterpenoids, $16 \alpha / \beta$-hydroxy-cleroda-3,13(14)Zdien-15,16-olide (1) and 16-oxo-cleroda-3,13(14)E-dien-15-oic acid (2), were isolated and identified as the cytotoxic compounds through bioassay-guided fractionation from the Acanthaceae family. Compound $\mathbf{1}$ showed greater selectivity towards in vitro cancer cells over normal cells. Compound 1 was established to induce apoptosis through both intrinsic and extrinsic pathways, which warrants the further investigation of compound $\mathbf{1}$ as an anticancer agent from an edible plant as with the potential of lower toxicity.

Supplementary Materials: The following are available online. Figure S1. Scheme showing the extraction, bioassay-guided purification, and identification of cytotoxic compound $\mathbf{1}$ and $\mathbf{2}$ from J. insularis. Figure S2: Mean concentration-response curve of the active extract of J. insularis (DCM/MeOH) in OVCAR 4 (A) and OVCAR 8 (B) ovarian cancer cell lines, showing potent cytotoxic activity of the organic extracts. Figure S3. Analytical HPLC chromatograms of purified active compounds of J.insularis. Figure S4: LC-HRMS chromatogram (A) and negative ESI-MS spectrum (B) of isolated compound 1 showing the HRMS of the major peak at a retention time of $12.87 \mathrm{~min}$. Figure S5: GC-MS chromatogram and mass spectra of the isolated compound 1 at Rt 18.45 min and two thermal degradation products of $\mathbf{1 a}$ and $\mathbf{1 b}$ under high temperature in the oven of GC-MS. Figure S6: NMR data analysis of $J$. insularis of the purified compound 1 and hexane fraction in $\mathrm{CDCl}_{3}:(\mathrm{A}){ }^{1} \mathrm{H}-\mathrm{NMR}$ (500 MHz), (B) ${ }^{13} \mathrm{C}$ NMR (125 MHz) spectrum, (C) ${ }^{13} \mathrm{C}-\mathrm{NMR}$ (100 MHz) spectrum (range of 110-180 $\mathrm{ppm}$ ) of hexane fraction containing 1 before silica gel chromatography and HPLC. Figure S7: LC-MS chromatogram (A) and negative ESI-MS spectrum (B) of isolated compound 2 at retention time of $13.45 \mathrm{~min}$. Figure S8: NMR spectra of J. insularis purified compound 2 in $\mathrm{CDCl}_{3}$ : (A) ${ }^{1} \mathrm{H}-\mathrm{NMR}$ and (B) ${ }^{13}$ C-NMR spectra. Figure S9. Distribution of predicted targets molecules of compound 1 by the SwissADME web tool (Table S5). Figure S10. Distribution of predicted targets molecules of compound 2 by the SwissADME web tool (Table S6). Table S1: The results of the growth inhibitory activities of $J$. insularis extracts and fractions on ovarian cancer OVCAR-4 and OVCAR-8 cell lines. Table S2: The growth inhibitory activities of EA fractions and EA4 sub-fractions of $J$. insularis on OVCAR-4 ovarian cancer cell line. Table S3: ${ }^{1} \mathrm{H}(500 \mathrm{MHz})$ and ${ }^{13} \mathrm{C}-\mathrm{NMR}(125 \mathrm{MHz})$ assignments of isolated compound 1 and $\mathbf{2}\left(\mathrm{CDCl}_{3}\right)$. Table S4. Molecular descriptors and drug-likeness of compounds 1 and $\mathbf{2}$ in J. insularis calculated by SwissADME web tool. Table S5. Predicted protein targets of compound 1 by SwissTargetPrediction web tool. Table S6. Predicted protein targets of compound 2 by SwissTargetPrediction web tool.

Author Contributions: I.E.F. performed the experimental work; O.R.J.-A. collected the plant materials and performed the initial plant extraction; E.P. and J.M. performed LC-MS analysis; T.D.W.C. performed NMR measurement; N.R.F. provided resources and advice; W.-W.L. and I.E.F. designed and conceived the studies and carried out structural determination and bioinformatic analysis; I.E.F. drafted, and all authors contributed to writing the article. All authors have read and agreed to the published version of the manuscript.

Funding: This research was funded by the Tertiary Education Trust Fund, Nigeria.

Institutional Review Board Statement: Not applicable. 
Informed Consent Statement: Not applicable.

Data Availability Statement: Data available within the article or Supplementary Materials.

Acknowledgments: We thank Sian Woodfine at Keele University for recording NMR spectra of the hexane fraction of J. insularis. We also thank Alexander Kagansky, Ted Hupp and Alan Richardson for advice and an anonymous reviewer for suggesting to use SwissADME web tools.

Conflicts of Interest: All authors do not have conflict of interest to disclose.

Sample Availability: Samples of the compounds are not available from the authors.

\section{References}

1. Torre, L.A.; Trabert, B.; DeSantis, C.E.; Miller, K.D.; Samimi, G.; Runowicz, C.D.; Gaudet, M.M.; Jemal, A.; Siegel, R.L. Ovarian cancer statistics, 2018. CA Cancer J. Clin. 2018, 68, 284-296. [CrossRef] [PubMed]

2. Li, W.W.; Johnson-Ajinwo, O.R.; Uche, F.I. Advances of Plant-Derived Natural Products in Ovarian Cancer Therapy. Int. J. Cancer Res. Prev. 2016, 9, 81-135.

3. Kuroki, L.; Guntupalli, S.R. Treatment of epithelial ovarian cancer. BMJ 2020, 371, m3773. [CrossRef]

4. Newman, D.J.; Cragg, G.M. Natural products as sources of new drugs from 1981 to 2014. J. Nat. Prod. 2016, 79, 629-661. [CrossRef] [PubMed]

5. Mandrich, L.; Caputo, E. Brassicaceae-Derived Anticancer Agents: Towards a Green Approach to Beat Cancer. Nutrients 2020, 12, 868. [CrossRef] [PubMed]

6. Madunic, J.; Madunic, I.V.; Gajski, G.; Popic, J.; Garaj-Vrhovac, V. Apigenin: A dietary flavonoid with diverse anticancer properties. Cancer Lett. 2018, 413, 11-22. [CrossRef] [PubMed]

7. Wang, H.; Khor, T.O.; Shu, L.; Su, Z.Y.; Fuentes, F.; Lee, J.H.; Kong, A.N. Plants vs. cancer: A review on natural phytochemicals in preventing and treating cancers and their druggability. Anticancer Agents Med. Chem. 2012, 12, 1281-1305. [CrossRef] [PubMed]

8. Bhaskar, B.V.; Rammohan, A.; Babu, T.M.; Zheng, G.Y.; Chen, W.; Rajendra, W.; Zyryanov, G.V.; Gu, W. Molecular insight into isoform specific inhibition of PI3K- $\alpha$ and PKC- $\eta$ with dietary agents through an ensemble pharmacophore and docking studies. Sci Rep. 2021, 11, 12150. [CrossRef]

9. Johnson-Ajinwo, O.R.; Richardson, A.; Li, W.W. Cytotoxic effects of stem bark extracts and pure compounds from Margaritaria discoidea on human ovarian cancer cell lines. Phytomedicine 2015, 22, 1-4. [CrossRef] [PubMed]

10. Uche, F.I.; Drijfhout, F.P.; McCullagh, J.; Richardson, A.; Li, W.W. Cytotoxicity Effects and Apoptosis Induction by Bisbenzylisoquinoline Alkaloids from Triclisia subcordata. Phytother. Res. 2016, 30, 1533-1539. [CrossRef]

11. Uche, F.I.; Abed, M.N.; Abdullah, M.I.; Drijfhout, F.P.; McCullagh, J.; Claridge, T.W.D.; Richardson, A.; Li, W.W. Isolation, identification and anti-cancer activity of minor alkaloids from Triclisia subcordata Oliv. Biochem Pharm. 2017, 139, 112. [CrossRef]

12. Uche, F.I.; Abed, M.N.; Abdullah, M.I.; Drijfhout, F.P.; McCullagh, J.; Claridge, T.W.D.; Richardson, A.; Li, W.W. Isochondodendrine and 2'-norcocsuline: Additional alkaloids from Triclisia subcordata induce cytotoxicity and apoptosis in ovarian cancer cell lines. Rsc Adv. 2017, 7, 44154-44161. [CrossRef]

13. Johnson-Ajinwo, O.R.; Richardson, A.; Li, W.W. Identification and evaluation of anticancer compounds from three Nigerian plants used in traditional medicines. Biochem. Pharm. 2017, 139, 128. [CrossRef]

14. Uche, F.I.; McCullagh, J.; Claridge, T.W.D.; Richardson, A.; Li, W.W. Synthesis of (aminoalkyl)cycleanine analogues: Cytotoxicity, cellular uptake, and apoptosis induction in ovarian cancer cells. Bioorg. Med. Chem. Lett. 2018, 28, 1652-1656. [CrossRef] [PubMed]

15. Johnson-Ajinwo, O.R.; Richardson, A.; Li, W.W. Palmatine from Unexplored Rutidea parviflora Showed Cytotoxicity and Induction of Apoptosis in Human Ovarian Cancer Cells. Toxins 2019, 11, 237. [CrossRef] [PubMed]

16. Uche, F.I.; Guo, X.; Okokon, J.; Ullah, I.; Horrocks, P.; Boateng, J.; Huang, C.; Li, W.W. In Vivo Efficacy and Metabolism of the Antimalarial Cycleanine and Improved In Vitro Antiplasmodial Activity of Semisynthetic Analogues. Antimicrob. Agents Chemother. 2021, 65, e01995-20. [CrossRef] [PubMed]

17. Telefo, P.B.; Moundipa, P.F.; Tchouanguep, F.M. Inductive effect of the leaf mixture extract of Aloe buettneri, Justicia insularis, Dicliptera verticillata and Hibiscus macranthus on in vitro production of estradiol. J. Ethnopharmacol. 2004, 91, 225-230. [CrossRef]

18. Ajibesin, K.K.; Ekpo, B.A.; Bala, D.N.; Essien, E.E.; Adesanya, S.A. Ethnobotanical survey of Akwa Ibom State of Nigeria. J. Ethnopharmacol. 2008, 115, 387-408. [CrossRef]

19. Telefo, P.B.; Tagne, S.R.; Koona, O.E.; Yemele, D.M.; Tchouanguep, F.M. Effect of the aqueous extract of Justicia insularis T. Anders (Acanthaceae) on ovarian folliculogenesis and fertility of female rats. Afr. J. Tradit. Complement. Altern. Med. 2012, 9, 197-203. [CrossRef] [PubMed]

20. Adeyemi, O.T.; Babatunde, O. Chemical composition and anti-oxidant capacity of the leaf extract of Justicia insularis. Intern. J. Phys. Sci. 2014, 9, 454-458.

21. Correa, G.M.; Alcantara, A.F.D. Chemical constituents and biological activities of species of Justicia-A review. Rev. Bras. Farm. 2012, 22, 220-238. [CrossRef]

22. Wood, J.; Yasmin-Karim, S.; Moreau, M.; Kumar, R.; Akwanwi, J.; Derek, A.; Atoneche, F.; Kress, J.; Ngwa, A.W. Characterization of Isolated Extracts from Justicia Plant Leaves used as Remedy for Anemia. Molecules 2020, 25, 534. [CrossRef] 
23. Logue, S.E.; Elgendy, M.; Martin, S.J. Expression, purification and use of recombinant annexin V for the detection of apoptotic cells. Nat. Protoc. 2009, 4, 1383-1395. [CrossRef]

24. Daina, A.; Michielin, O.; Zoete, V. SwissADME: A free web tool to evaluate pharmacokinetics, drug-likeness and medicinal chemistry friendliness of small molecules. Sci Rep. 2017, 7, 42717. [CrossRef]

25. Available online: http://www.swissadme.ch/index.php (accessed on 23 September 2021).

26. Available online: http:/ / www.swisstargetprediction.ch/ (accessed on 23 September 2021).

27. Daina, A.; Michielin, O.; Zoete, V. SwissTargetPrediction: Updated data and new features for efficient prediction of protein targets of small molecules. Nucleic Acids Res. 2019, 47, W357-W364. [CrossRef]

28. Phadnis, A.P.; Patwardhan, S.A.; Dhaneshwar, N.N.; Tavale, S.S.; Row, T.N.G. Clerodane Diterpenoids from Polyalthia-longifolia. Phytochemistry 1988, 27, 2899-2901. [CrossRef]

29. Hara, N.; Asaki, H.; Fujimoto, Y.; Gupta, Y.K.; Singh, A.K.; Sahai, M. Clerodane and Ent-Halimane Diterpenes from Polyalthialongifolia. Phytochemistry 1995, 38, 189-194. [CrossRef]

30. Muller, D.S.; Untiedt, N.L.; Dieskau, A.P.; Lackner, G.L.; Overman, L.E. Constructing Quaternary Stereogenic Centers Using Tertiary Organocuprates and Tertiary Radicals. Total Synthesis of trans-Clerodane Natural Products. J. Am. Chem. Soc. 2015, 137, 660-663. [CrossRef] [PubMed]

31. Joseph, L.; Aranjani, J.M.; Pai, K.S.; Srinivasan, K.K. Promising anticancer activities of Justicia simplex D. Don. in cellular and animal models. J. Ethnopharmacol. 2017, 199, 231-239. [CrossRef] [PubMed]

32. He, X.L.; Zhang, P.; Dong, X.Z.; Yang, M.H.; Chen, S.L.; Bi, M.G. JR6, a new compound isolated from Justicia procumbens, induces apoptosis in human bladder cancer EJ cells through caspase-dependent pathway. J. Ethnopharmacol 2012, 144, 284-292. [CrossRef] [PubMed]

33. Lv, J.P.; Yang, S.; Dong, J.X.; Jin, H. New cyclopeptide alkaloids from the whole plant of Justicia procumbens L. Nat. Prod. Res. 2020, 1-9. [CrossRef]

34. Li, R.; Morris-Natschke, S.L.; Lee, K.H. Clerodane diterpenes: Sources, structures, and biological activities. Nat. Prod. Rep. 2016, 33, 1166-1226. [CrossRef]

35. Ma, X.; Lee, I.S.; Chai, H.B.; Zaw, K.; Farnsworth, N.R.; Soejarto, D.D.; Cordell, G.A.; Pezzuto, J.M.; Kinghorn, A.D. Cytotoxic clerodane diterpenes from Polyalthia barnesii. Phytochemistry 1994, 37, 1659-1662. [CrossRef]

36. Duan, X.Y.; Guo, K.Y.; Lv, D.J.; Mei, R.Q.; Zhang, M.D. Terpenes isolated from Polyalthia simiarum and their cytotoxic activities. Fitoterapia 2020, 147, 104734. [CrossRef]

37. Fukamiya, N.; Lee, K.H. Antitumor agents, 81. Justicidin-A and diphyllin, two cytotoxic principles from Justicia procumbens. J. Nat. Prod. 1986, 49, 348-350. [CrossRef]

38. Lee, J.C.; Lee, C.H.; Su, C.L.; Huang, C.W.; Liu, H.S.; Lin, C.N.; Won, S.J. Justicidin A decreases the level of cytosolic Ku70 leading to apoptosis in human colorectal cancer cells. Carcinogenesis 2005, 26, 1716-1730. [CrossRef]

39. Elmore, S. Apoptosis: A review of programmed cell death. Toxicol. Pathol. 2007, 35, 495-516. [CrossRef] [PubMed]

40. Bhullar, K.S.; Lagaron, N.O.; McGowan, E.M.; Parmar, I.; Jha, A.; Hubbard, B.P.; Rupasinghe, H.P.V. Kinase-targeted cancer therapies: Progress, challenges and future directions. Mol. Cancer 2018, 17, 48. [CrossRef] [PubMed]

41. Sari, D.P.; Ninomiya, M.; Efdi, M.; Santoni, A.; Ibrahim, S.; Tanaka, K.; Koketsu, M. Clerodane diterpenes isolated from Polyalthia longifolia induce apoptosis in human leukemia HL-60 cells. J. Oleo Sci. 2013, 62, 843-848. [CrossRef] [PubMed]

42. Lin, Y.H.; Lee, C.C.; Chang, F.R.; Chang, W.H.; Wu, Y.C.; Chang, J.G. 16-hydroxycleroda-3,13-dien-15,16-olide regulates the expression of histone-modifying enzymes PRC2 complex and induces apoptosis in CML K562 cells. Life Sci. 2011, 89, 886-895. [CrossRef] [PubMed]

43. Lin, Y.H.; Lee, C.C.; Chan, W.L.; Chang, W.H.; Wu, Y.C.; Chang, J.G. 16-Hydroxycleroda-3,13-dien-15,16-olide deregulates PI3K and Aurora B activities that involve in cancer cell apoptosis. Toxicology 2011, 285, 72-80. [CrossRef] [PubMed]

44. Cheng, M.F.; Lin, S.R.; Tseng, F.J.; Huang, Y.C.; Tsai, M.J.; Fu, Y.S.; Weng, C.F. The autophagic inhibition oral squamous cell carcinoma cancer growth of 16-hydroxy-cleroda-3,14-dine-15,16-olide. Oncotarget 2017, 8, 78379-78396. [CrossRef] [PubMed]

45. Liu, C.; Lee, W.C.; Huang, B.M.; Chia, Y.C.; Chen, Y.C.; Chen, Y.C. 16-Hydroxycleroda-3, 13-dien-15, 16-olide inhibits the proliferation and induces mitochondrial-dependent apoptosis through Akt, mTOR, and MEK-ERK pathways in human renal carcinoma cells. Phytomedicine 2017, 36, 95-107. [CrossRef]

46. Chen, Y.C.; Huang, B.M.; Lee, W.C.; Chen, Y.C. 16-Hydroxycleroda-3,13-dien-15,16-olide induces anoikis in human renal cell carcinoma cells: Involvement of focal adhesion disassembly and signaling. OncoTargets Ther. 2018, 11, 7679-7690. [CrossRef]

47. Chen, Y.C.; Wang, P.Y.; Huang, B.M.; Chen, Y.J.; Lee, W.C.; Chen, Y.C. 16-Hydroxycleroda-3,13-dien-15,16-olide Induces Apoptosis in Human Bladder Cancer Cells through Cell Cycle Arrest, Mitochondria ROS Overproduction, and Inactivation of EGFR-Related Signalling Pathways. Molecules 2020, 25, 3958. [CrossRef]

48. Velmurugan, B.K.; Wang, P.C.; Weng, C.F. 16-Hydroxycleroda-3,13-dien-15,16-olide and N-Methyl-Actinodaphine Potentiate Tamoxifen-Induced Cell Death in Breast Cancer. Molecules 2018, 23, 1966. [CrossRef]

49. Misra, P.; Sashidhara, K.V.; Singh, S.P.; Kumar, A.; Gupta, R.; Chaudhaery, S.S.; Gupta, S.S.; Majumder, H.K.; Saxena, A.K.; Dube, A. 16alpha-Hydroxycleroda-3,13 (14)Z-dien-15,16-olide from Polyalthia longifolia: A safe and orally active antileishmanial agent. Br. J. Pharm. 2010, 159, 1143-1150. [CrossRef] 
50. Sashidhara, K.V.; Singh, S.P.; Srivastava, A.; Puri, A.; Chhonker, Y.S.; Bhatta, R.S.; Shah, P.; Siddiqi, M.I. Discovery of a new class of HMG-CoA reductase inhibitor from Polyalthia longifolia as potential lipid lowering agent. Eur. J. Med. Chem. 2011, 46, 5206-5211. [CrossRef] [PubMed]

51. Nguyen, H.T.; Vu, T.Y.; Chandi, V.; Polimati, H.; Tatipamula, V.B. Dual COX and 5-LOX inhibition by clerodane diterpenes from seeds of Polyalthia longifolia (Sonn.) Thwaites. Sci. Rep. 2020, 10, 15965. [CrossRef] [PubMed]

52. Wu, T.H.; Cheng, Y.Y.; Chen, C.J.; Ng, L.T.; Chou, L.C.; Huang, L.J.; Chen, Y.H.; Kuo, S.C.; El-Shazly, M.; Wu, Y.C.; et al. Three new clerodane diterpenes from Polyalthia longifolia var. pendula. Molecules 2014, 19, 2049-2060. [CrossRef]

53. Khan, A.K.; Ahmed, A.; Hussain, M.; Khan, I.A.; Ali, S.A.; Farooq, A.D.; Faizi, S. Antibiofilm potential of 16-oxo-cleroda-3, 13(14) E-diene-15 oic acid and its five new gamma-amino gamma-lactone derivatives against methicillin resistant Staphylococcus aureus and Streptococcus mutans. Eur. J. Med. Chem. 2017, 138, 480-490. [CrossRef]

54. Islam, M.T. Diterpenes and Their Derivatives as Potential Anticancer Agents. Phytother. Res. 2017, 31, 691-712. [CrossRef]

55. Kampan, N.C.; Madondo, M.T.; McNally, O.M.; Quinn, M.; Plebanski, M. Paclitaxel and Its Evolving Role in the Management of Ovarian Cancer. Biomed. Res. Int. 2015, 2015, 413076. [CrossRef]

56. Huang, D.M.; Shen, Y.C.; Wu, C.; Huang, Y.T.; Kung, F.L.; Teng, C.M.; Guh, J.H. Investigation of extrinsic and intrinsic apoptosis pathways of new clerodane diterpenoids in human prostate cancer PC-3 cells. Eur. J. Pharm. 2004, 503, 17-24. [CrossRef] [PubMed]

57. Dai, S.J.; Sun, J.Y.; Ren, Y.; Liu, K.; Shen, L. Bioactive ent-clerodane diterpenoids from Scutellaria barbata. Planta Med. 2007, 73, 1217-1220. [CrossRef] [PubMed]

58. Liang, Y.; Zhang, Q.; Yang, X.; Li, Y.; Zhang, X.; Li, Y.; Du, Q.; Jin, D.Q.; Cui, J.; Lall, N.; et al. Diterpenoids from the leaves of Casearia kurzii showing cytotoxic activities. Bioorg. Chem. 2020, 98, 103741. [CrossRef] [PubMed] 